\title{
Public Policy
}

National Cancer Institute

\section{Source}

National Cancer Institute. Public Policy. NCI Thesaurus. Code C17041.

The basic policy or set of policies forming the foundation of public laws, especially such policy not yet formally enunciated. (dictionary.com) 